\title{
ANNOTATIES
}

\section{IPR-problemen in de WOR en het enquêterecht}

\author{
Ondernemingskamer 21 december 2012, JAR 2013/67 (VLM II) \\ en HR 29 maart 2013, JOR 2013/166 (Chinese Workers)
}

\author{
F.G. Laagland
}

\section{Inleiding}

De Ondernemingskamer heeft zich in korte tijd tweemaal moeten buigen over een kwestie met een internationaal karakter: in een zaak met betrekking tot de Wet op de ondernemingsraden (WOR) en in een enquêtezaak. In de VLM IIbeschikking van 21 december 2012 liet de Ondernemingskamer zich voor het eerst uit over haar bevoegdheid in een internationaal medezeggenschapsgeschil. ${ }^{1}$ In de procedure was een buitenlandse vennootschap als medeondernemer betrokken. De Ondernemingskamer achtte zich (ook) jegens de buitenlandse vennootschap bevoegd over het geschil te oordelen. Eerder dat jaar werd de Ondernemingskamer met een soortgelijke situatie geconfronteerd op het terrein van het enquêterecht. In de zaak Chinese Workers verzocht een aandeelhouder van een buitenlandse moedervennootschap een onderzoek ten aanzien van het beleid en de gang van zaken in de Nederlandse dochtervennootschap. De Ondernemingskamer verklaarde de indirect aandeelhouder enquêtegerechtigd. ${ }^{2}$ Op 29 maart 2013 bevestigde de Hoge Raad tot verbazing van sommigen de beschikking van de Ondernemingskamer. ${ }^{3}$

In deze bijdrage ga ik na hoe de Ondernemingskamer in WOR- en enquêtezaken omgaat met vragen van internationaal-privaatrechtelijke aard. Het onderzoek verricht ik aan de hand van de beschikkingen inzake VLM II en Chinese Workers. Alvorens de twee beschikkingen te vergelijken, worden de feiten van en het procesverloop in beide zaken uiteengezet. Hierna wordt ingezoomd op de rol van de Ondernemingskamer vanuit het gezichtspunt van het internationale privaatrecht (IPR). Het IPR maakt een onderscheid tussen het internationale bevoegdheidsrecht (formeel IPR) en het conflictenrecht (materieel IPR). De rol van de Ondernemingskamer tekent zich aldus op twee deelgebieden af. Het gaat om: (1) de competentie van de Ondernemingskamer en (2) haar beslissingen over de toepassing van de WOR en het enquêterecht. Ik analyseer de wijze waarop de Ondernemingskamer met beide IPR-kwesties omgaat in VLM II en Chinese Workers. Speciale aandacht komt toe aan de vraag of tussen de benadering van de Ondernemingskamer in beide zaken verbanden zijn te ontdekken.

1 Hof Amsterdam (OK) 21 december 2012, JAR 2013/67 m.nt. Haanappel-van der Burg (VLM II).

2 Hof Amsterdam (OK) 7 februari 2012, JOR 2012/143 m.nt. Doorman (Chinese Workers).

3 HR 29 maart 2013, JOR 2013/166 m.nt. Doorman (Chinese Workers). 
F.G. Laagland

\section{De zaak VLM II}

De Nederlandse vennootschap VLM Nederland B.V. maakt onderdeel uit van het internationale concern Air-France-KLM. De grootmoedervennootschap CityJet Ltd. is gevestigd in Dublin. Daaronder hangt de Belgische vennootschap VLM Airlines N.V., die op haar beurt $100 \%$ van de aandelen houdt in en enig bestuurder is van VLM Nederland. Bij VLM Nederland is een ondernemingsraad ingesteld.

VLM Nederland en haar ondernemingsraad stonden in 2010 al eerder tegenover elkaar bij de Ondernemingskamer. Het geschil had toen betrekking op het toepassen van een wetleaseovereenkomst op VLM Nederland. Een wetleaseovereenkomst is een overeenkomst tussen twee luchtvaartmaatschappijen, waarbij de ene maatschappij vliegtuigen, bemanning, onderhoud en verzekering ter beschikking stelt aan een andere maatschappij, die hiervoor per uur betaalt. De wetleaseovereenkomst in deze zaak zag op de vliegroute Eindhoven-Londen. VLM Airlines leverde vliegtuigen en bemanning voor de door CityJet uit te voeren vluchten. Het voor de vluchten in te zetten personeel werd verschaft door VLM Nederland. De ondernemingsraad meende dat hem over het invoeren van de wetleaseconstructie op VLM Nederland en de daarmee samenhangende wijziging van de statuten ten onrechte geen advies was gevraagd. De Ondernemingskamer stelde de ondernemingsraad in het gelijk. Hoewel VLM Airlines en niet VLM Nederland tot het invoeren van de wetleaseovereenkomst had besloten, had het besluit een ingrijpende beleidswijziging voor de door VLM Nederland in stand gehouden onderneming tot gevolg. De Ondernemingskamer was bovendien van oordeel dat VLM Airlines als medeondernemer kon worden beschouwd. De Hoge Raad liet het oordeel van de Ondernemingskamer in stand en verwierp het cassatieberoep met verwijzing naar artikel 81 van de Wet op de rechterlijke organisatie (Wet RO). ${ }^{4}$

De zaak die leidde tot de beschikking van 21 december 2012 ligt in het verlengde van het geschil uit 2010. Op 3 februari 2012 en - na opschorting van de besluitvorming - wederom op 3 oktober 2012 vroeg VLM Nederland aan haar ondernemingsraad advies over het voorgenomen besluit tot stopzetting van de vliegroute Eindhoven-Londen en de opheffing van Eindhoven als basis voor activiteiten van VLM Nederland. De reden voor het besluit was dat de vliegroute Eindhoven-Londen verliesgevend was en naar verwachting verliesgevend zou blijven. De ondernemingsraad adviseerde negatief. Op 9 november 2012 besloot VLM Nederland overeenkomstig haar adviesaanvraag. De ondernemingsraad vorderde in kort geding dat aan VLM Nederland een verbod werd opgelegd tot 9 december 2012 over te gaan tot uitvoering van voormelde besluiten. De ondernemingsraad had reden te vermoeden dat VLM Nederland de wettelijke opschortingstermijn van een maand niet in acht zou nemen. De voorzieningenrechter wees de vordering toe. $^{5}$

De ondernemingsraad stelde op 28 november 2012 beroep in bij de Ondernemingskamer. De ondernemingsraad verzocht de Ondernemingskamer te verklaren dat de ondernemer in redelijkheid niet tot de voornoemde besluiten had

4 HR 3 februari 2012, JAR 2012/71 (VLM I) m.nt. Van het Kaar in TRA 2012/39.

5 Ktr. (vzr.) Rotterdam 13 november 2012, JAR 2013/83. 
kunnen komen en hem te verplichten de besluiten in te trekken, alsmede alle gevolgen ongedaan te maken en enige handeling te verrichten ter uitvoering van de besluiten. Het verzoek richtte zich tegen VLM Nederland als eigen ondernemer en tegen de moeder VLM Airlines en de grootmoeder CityJet als medeondernemers. De ondernemingsraad meende dat VLM Nederland de besluiten mede namens VLM Airlines en CityJet had genomen. CityJet wierp ter verweer op dat zij is gevestigd in Dublin (Ierland). Het feit dat CityJet werd beheerst door buitenlands recht zou maken dat de Ondernemingskamer op grond van artikel 2 EEX-Verordening niet bevoegd was jegens haar over het verzoek van de ondernemingsraad te oordelen. Het valt op dat dit punt in de procedure uit 2010 niet naar voren is gebracht. In die procedure was CityJet weliswaar niet als verweerder betrokken, maar VLM Airlines wel. Ook VLM Airlines is in het buitenland (België) gevestigd. VLM Airlines beriep zich evenmin in de onderhavige procedure op de onbevoegdheid van de Ondernemingskamer.

Het onbevoegdheidsverweer van CityJet vond geen gehoor bij de Ondernemingskamer. De Ondernemingskamer oordeelde dat de EEX-Verordening - wat betreft het materiële toepassingsgebied - niet van toepassing was en achtte zich bevoegd van het geschil jegens CityJet kennis te nemen. Deze overweging leverde de ondernemingsraad niet de eindwinst op. De Ondernemingskamer overwoog dat de ondernemingsraad onvoldoende had bestreden dat de route Eindhoven-Londen structureel verliesgevend was. Hierdoor kon niet worden gezegd dat VLM Nederland bij afweging van de betrokken belangen niet in redelijkheid tot haar besluit had kunnen komen. De vraag of VLM Airlines en/of CityJet als medeondernemer waren te beschouwen, behoefde hierom geen beantwoording. De Ondernemingskamer merkte nog op dat een bevestigend antwoord ook niet tot een andere uitkomst van het geding zou hebben geleid.

\section{De zaak Chinese Workers}

In de zaak Chinese Workers is eveneens sprake van een buitenlands concern. De moedervennootschap Chinnede Ltd. is gevestigd in Hongkong. De aandelen van Chinnede zijn in handen van vier natuurlijke personen. Over de precieze verdeling van het aandeelhouderschap bestaat discussie. ${ }^{6}$ Chinnede is $100 \%$ aandeelhouder en enig bestuurder van de Nederlandse vennootschap Chinese Workers, die een onderneming drijft gericht op het detacheren van uit China afkomstig horecapersoneel in Nederland.

Yeh-Chiu - een van de aandeelhouders van de buitenlandse moedervennootschap - verzocht op 10 november 2011 een enquête om het beleid en de gang van zaken bij de Nederlandse dochter Chinese Workers te onderzoeken. Het verzoek strekte er kort gezegd toe dat de Ondernemingskamer bij beschikking, uitvoerbaar bij voorraad: (1) een onderzoek zou bevelen naar het beleid en de gang van zaken van Chinese Workers en (2) bij wijze van onmiddellijke voorziening voor de

6 Over het aandeelhouderschap in Chinnede loopt een procedure in Hongkong. Zoals de Ondernemingskamer terecht opmerkt, is dit detail niet relevant voor de uitkomst van het geding. 
F.G. Laagland

duur van het geding een onafhankelijke derde zou benoemen als bestuurder van Chinese Workers, belast met de dagelijkse leiding over de onderneming. Centraal in de procedure stond de vraag of Yeh-Chiu als aandeelhouder van de buitenlandse moeder al dan niet enquêtegerechtigd was ten opzichte van de Nederlandse dochter. Naar de letter van artikel 2:346 sub b Burgerlijk Wetboek (BW) (oud) ${ }^{7}$ is enquêtegerechtigd degene die houder is van aandelen of certificaten van aandelen in het geplaatst kapitaal van de vennootschap waarop het verzoek betrekking heeft (de juridisch eigenaar). Hieraan voldeed Yeh-Chiu niet. Zij hield aandelen in de moeder en niet in de dochter. Het is evenwel vaste rechtspraak dat ook enquêtegerechtigd is de verschaffer van risicodragend kapitaal met een eigen economisch belang - in de zin van een vorderingsrecht jegens de juridisch rechthebbende - in de vennootschap waarop het verzoek zich richt (de economisch gerechtigde). ${ }^{8}$ Op deze uitbreiding van de kring van enquêtegerechtigden deed Yeh-Chiu een beroep in haar relatie tot de dochtervennootschap.

De Ondernemingskamer volgde Yeh-Chiu in haar betoog. De Ondernemingskamer achtte van belang dat (1) Chinnede uitsluitend de aandelen van Chinese Workers beheerde en verder geen ondernemingsactiviteiten verrichtte, (2) er geen reden was voor het beheer vanuit Hongkong, (3) alle ondernemingsactiviteiten door of in opdracht van Chinese Workers werden verricht (dit geldt ook voor de werving van horecapersoneel in China), en (4) de door de uitzendbureaus verschuldigde commissie door Yeh-Chiu werd gefactureerd en door de uitzendbureaus rechtstreeks aan de aandeelhouders van Chinnede werd betaald. Onder dergelijke omstandigheden billijkte de economische werkelijkheid een uitzondering op de hoofdregel van artikel 2:346 sub b BW, aldus de Ondernemingskamer.

De overige drie aandeelhouders van Chinnede tekenden cassatieberoep aan. Advocaat-generaal Vlas concludeerde bij conclusie van 21 december 2012 tot vernietiging van de beschikking van de Ondernemingskamer vanwege het slagen van het cassatiemiddel, voor zover dat erop was gericht 'dat de Ondernemingskamer een te ruime maatstaf heeft aangelegd bij de beoordeling van de ontvankelijkheidsvraag' (r.o. 2.13). De advocaat-generaal baseerde zijn oordeel grotendeels op de TESN-beschikking van de Hoge Raad uit 2011. ${ }^{9}$ In TESN had de Hoge Raad eveneens moeten oordelen over een enquêteverzoek van een persoon die een indirect belang had in de Nederlandse vennootschap waarop het enquêteverzoek

7 Sinds 1 januari 2013 is de pendant van artikel 2:346 onder b BW te vinden in artikel 2:346 lid 1 onder b-c BW. De vragen die spelen in de Chinese Workers-beschikking zijn net zo goed relevant voor de toepassing van het huidige artikel 2:346 lid 1 onder b-c BW. In het vervolg van deze bijdrage wordt - conform de uitspraak - steeds het oude artikel genoemd.

8 HR 6 juni 2003, NJ 2003, 486 m.nt. Ma, JOR 2003/161 m.nt. Josphus Jitta (Scheipar); HR 10 september 2010, NJ 2010, 665 m.nt. Van Schilgaarde \& Perrick, JOR 2010/337 m.nt. Brink (Butôt); HR 8 april 2011, NJ 2011, 338 m.nt. Van Schilfgaarde, JOR 2011/178 m.nt. Doorman (TESN). Zie voor een uitgebreide uiteenzetting van het begrip economisch gerechtigde Asser/ Maeijer/Van Solinge \& Nieuwe Weme 2009 (2-II*), nr. 738; G. van Solinge, Doorbraak van enquêtebevoegdheid in internationale concernverhoudingen, in: F. Ibili, M.E. Koppeno-Laforce \& M. Zilinsky (red.), IPR in de spiegel van Paul Vlas, Deventer: Kluwer 2012, p. 199-202 en G. van Solinge, Nederlands enquêterecht in internationale concernverhoudingen: Bermuda Block of China Connection? TAO 2012/3-4, p. 85-91.

$9 \quad$ HR 8 april 2011, NJ 2011, 338 m.nt. Van Schilfgaarde, JOR 2011/178 m.nt. Doorman (TESN). 
zich richtte. In deze zaak speelde een ingewikkelde internationale juridische structuur. De aandelen in de Nederlandse vennootschap TESN werden gehouden door twee buitenlandse Antilliaanse vennootschappen waarvan de aandelen via een trustconstructie in handen waren van een Bermudaanse vennootschap. Het viertal Bermudaanse trusts was naar evenredigheid verdeeld over twee broers. Een van de broers (Mark Bamford) wendde zich tot de Ondernemingskamer met het verzoek tot het instellen van een onderzoek naar het beleid en de gang van zaken van de Nederlandse vennootschap. In navolging van de Ondernemingskamer achtte de Hoge Raad Mark Bamford niet-ontvankelijk. ${ }^{10}$ De twee Antilliaanse vennootschappen - die om fiscale redenen waren tussen geplaatst konden niet worden 'weggedacht'. In de visie van advocaat-generaal Vlas rechtvaardigden de door de Ondernemingskamer vastgestelde omstandigheden in Chinese Workers niet dat de naar Chinees recht (bedoeld zal zijn: Hongkongs recht) opgerichte moedervennootschap nu wel kon worden weggedacht voor de vraag wie enquêtegerechtigd is.

De Hoge Raad volgde zijn advocaat-generaal niet. De Hoge Raad overwoog bij beschikking van 13 maart 2013 dat Yeh-Chiu zich ten opzichte van de Nederlandse dochtervennootschap als economisch gerechtigde kwalificeerde en dus binnen de kring van enquêtegerechtigden viel. Yeh-Chiu, als indirecte aandeelhouder, had als verschaffer van risicodragend kapitaal een eigen economisch belang in de dochtervennootschap, dat in zoverre kon worden gelijkgesteld met het belang van een aandeelhouder als bedoeld in artikel 2:346 sub b BW. Dat de verzoeker de aandelen in de dochtervennootschap niet rechtstreeks hield, deed aan dit oordeel niet af. Ook het feit dat de moedervennootschap een vennootschap naar buitenlands recht was, leidde niet tot een ander oordeel, aangezien alle ondernemingsactiviteiten plaatsvonden in de Nederlandse vennootschap en de moeder in feite niet meer was dan een administratiekantoor. Anders dan in de TESN-beschikking werd de buitenlandse moedervennootschap nu dus wel 'weggedacht' voor de toepassing van het enquêterecht (het verschil tussen beide beschikkingen komt aan de orde in paragraaf 4.3.2).

\section{Commentaar}

\subsection{De positie van de Ondernemingskamer in de WOR en het enquêterecht}

De Ondernemingskamer neemt binnen de Nederlandse rechterlijke organisatie een bijzondere plaats in. De Ondernemingskamer vindt haar grondslag in arti-

10 De voornaamste reden voor de niet-ontvankelijkheid was dat verzoeker slechts een afgeleid belang en geen vorderingsrecht had ten aanzien van de aandelen van de vennootschap waarop het verzoek zich richtte. Hij was daarom niet gelijk te stellen met een economisch gerechtigde die voor eigen rekening en risico de aandelen in de vennootschap houdt. De doorbraakvraag speelde slechts een ondergeschikte rol. 
F.G. Laagland

kel 66 Wet RO. Haar taak ligt onder meer verankerd in Boek 2 van het Burgerlijk Wetboek en in de WOR. ${ }^{11}$

De Nederlandse wet kent sinds 1929 de mogelijkheid de rechter te verzoeken onderzoekers te benoemen die worden belast met een onderzoek naar het beleid en de gang van zaken van een rechtspersoon. De reden om de Ondernemingskamer in 1971 bevoegd te maken als enige rechter in feitelijke instantie werd door de commissie-Verdam als volgt gemotiveerd: 'Niet alleen wordt van de rechter veel tact verlangd - alleen reeds het feit dat een verzoek wordt gedaan, betekent dat de onderneming in opspraak wordt gebracht - ook wordt, met name bij de maatregelen, genoemd in het ontworpen artikel 54, van de rechter een deskundig inzicht in de behoeften van en de verhoudingen in het bedrijfsleven gevergd. (...) Verwacht mag worden dat deze kamer [lees: de Ondernemingskamer] en door haar samenstelling en door haar ervaring zal beschikken over een bijzondere deskundigheid op het onderhavige gebied.' Deze overwegingen zijn onderschreven door de Sociaal-Economische Raad (SER) ${ }^{12}$ en de wetgever. ${ }^{13}$

Acht jaar later - bij wet van 1979 - kreeg de Ondernemingskamer een soortgelijke rol toebedeeld ten aanzien van het beroep van de ondernemingsraad tegen zogenoemde artikel 25 WOR-besluiten van de ondernemer. Artikel 25 WOR geeft een limitatieve opsomming van sociaaleconomische besluiten waarover de ondernemingsraad een recht tot advies heeft. Wordt het advies niet gevolgd of niet gevraagd, dan kan de ondernemingsraad zich tot de Ondernemingskamer wenden met het verzoek het besluit kennelijk onredelijk te achten en aan de ondernemer bepaalde voorzieningen op te leggen. Volgens de SER maakte de samenstelling van de Ondernemingskamer haar bij uitstek geschikt te oordelen over de bedrijfsen sociaaleconomische zaken die het voorwerp zijn van het beroep van de ondernemingsraad. Daarnaast werd relevant geacht dat de Ondernemingskamer reeds was belast met de toepassing van het aan het beroepsrecht enigszins verwante enquêterecht. ${ }^{14}$ In overeenstemming met het advies van de SER werd de Ondernemingskamer bij wijziging van de WOR in 1979 de enige bevoegde rechter in feitelijke instantie in artikel 25 WOR-zaken. ${ }^{15}$

De wetsgeschiedenis leert dat de Nederlandse wetgever het van belang achtte dat een bijzondere rechter oordeelt over geschillen met betrekking tot artikel 25 WOR-besluiten en enquêteverzoeken. De reden blijkt gelegen in de aard van de onderwerpen. In zowel artikel 25 WOR-zaken als enquêtezaken wordt van de rechter een deskundig inzicht in de behoeften van en de verhouding in het bedrijfsleven gevergd.

11 De taak van de Ondernemingskamer strekt verder dan het enquêterecht en de WOR. Zij heeft als rechterlijke instantie ook een taak bij de geschillenregeling in hoger beroep, de jaarrekeningprocedure, bepaalde kwesties inzake fusie en splitsing en de Wet op de Europese ondernemingsraden.

12 SER-advies 19 mei 1967, nr. 5, p. 5.

13 Kamerstukken II 1967/68, 9596, nr. 3, p. 5.

14 SER-advies 13 oktober 1972, nr. 72/16, p. 11.

15 Wet van 5 juli 1979, Stb. 448 (wetsontwerp 13 954). Zie ook: Kamerstukken II 1974/75, 13 350, nr. 3, p. 7. 
In het nationale rechtsverkeer doen zich geen problemen voor. Is de WOR dan wel het enquêterecht op de rechtsbetrekking van toepassing, dan is de Ondernemingskamer als enige feitelijke instantie bevoegd over het geschil te oordelen. Het wordt lastig bij een grensoverschrijdende kwestie zoals speelde in de zaken VLM II en Chinese Workers. Een rechtsgeschil is grensoverschrijdend zodra het aanknopingspunten heeft met meerdere staten. Dat kan te maken hebben met de nationaliteit van de procespartijen of de plaats van het onderwerp waarop het geschil betrekking heeft. Bij een grensoverschrijdende kwestie komt het IPR om de hoek kijken. Het gaat in het IPR om twee te onderscheiden aspecten: (1) de internationale bevoegdheid van de rechter (rechtsmacht) en (2) zijn oordeel over het op het internationale rechtsgeschil toepasselijke recht. De wetsgeschiedenis gaat niet in op de verhouding tussen de internationale bevoegdheid van de Ondernemingskamer en de toepassing van de WOR dan wel het enquêterecht op een internationale rechtsbetrekking. Het feit dat de Ondernemingskamer in de WOR en het enquêterecht als de bevoegde rechter is genoemd, creëert nog geen rechtsmacht. De regel dat distributie van rechtsmacht de attributie van rechtsmacht schept, is met de inwerkingtreding van het nieuwe procesrecht op 1 januari 2002 verlaten. ${ }^{16}$ Vanuit IPR-perspectief moet de bevoegdheidsvraag los van het toepasselijke recht worden beoordeeld.

\subsection{De internationale bevoegdheid van de Ondernemingskamer}

Het internationale bevoegdheidsrecht omvat regels met betrekking tot de vraag welke zaken met een grensoverschrijdende dimensie de nationale rechter al dan niet mag beslechten. In beginsel bepaalt elke staat zelf of zijn nationale gerechten internationaal bevoegd zijn of, anders gezegd, rechtsmacht hebben. Deze regels zijn voor Nederland neergelegd in de artikelen 1-14 van het Wetboek van Rechtsvordering $(\mathrm{Rv})$. Het commune formele IPR van een staat wordt evenwel opzij gezet door internationale instrumenten zoals verordeningen en verdragen. Binnen de Europese Unie is het belangrijkste instrument de EEX-Verordening (hierna EEX-Vo.). ${ }^{17}$ De EEX-Vo. geldt sinds 1 maart 2002 voor alle lidstaten van de Europese Unie en is van toepassing op burgerlijke en handelszaken.

\subsubsection{De materiële werkingssfeer van de EEX-Vo. en de WOR}

Het is de vraag of de EEX-Vo. van toepassing is indien het beroep van de ondernemingsraad zich richt tegen een artikel 25 WOR-besluit van een (mede)ondernemer met vestigingsplaats buiten Nederland, maar binnen de Europese Unie. De

16 P. Vlas, Rechtspersonen (praktijkreeks IPR, deel 9), Deventer: Kluwer 2009, p. 151.

17 Verordening nr. 44/2001 van de Raad van 22 december 2000, betreffende de rechterlijke bevoegdheid, de erkenning en de tenuitvoerlegging van beslissingen in burgerlijke en handelszaken (EEX-Verordening) (PbEG 2001, L 12), zoals laatstelijk gewijzigd op 22 februari 2012 (PbEU 2012, L 50). In december 2012 hebben het Europees Parlement en de Raad EEX-Vo. nr. 1215/2012 aangenomen, die van toepassing zal zijn op procedures die zijn ingesteld na 10 januari 2015 (PbEU 2012, L 351/1). Ik laat de wijzigingen hier rusten, omdat de huidige en de nieuwe regeling op de door mij te bespreken punten inhoudelijk hetzelfde zijn. Wel heeft een vernummering van de artikelen plaatsgevonden. Dit artikel sluit aan bij de nummering uit Verordening 44/2001. 
F.G. Laagland

Ondernemingskamer oordeelde in VLM II van niet. Vanuit de literatuur is op dit oordeel kritiek geuit. Haanappel-van der Burg meent dat internationale medezeggenschapsgeschillen onder de materiële werkingssfeer van de EEX-Vo. vallen. ${ }^{18}$ Volgens haar is de ondernemingsraad een privaatrechtelijk orgaan en heeft het door de ondernemingsraad ingestelde verzoek tot doel privaatrechtelijke belangen te waarborgen. Ook Zaal vindt het oordeel van de Ondernemingskamer niet steekhoudend. ${ }^{19} \mathrm{Zij}$ acht van belang dat in de EEX-Vo. noch in de jurisprudentie een uitzondering wordt gemaakt voor medezeggenschapszaken, terwijl de aard van het geschil een handelszaak lijkt te zijn.

Ik deel de kritiek van beide auteurs niet. De term burgerlijke en handelszaken is een autonoom begrip. Het onderwerp van het geding is relevant. Medezeggenschap draagt geen civielrechtelijk karakter. De ondernemingsraad is een bij wet ingesteld orgaan dat exclusief bevoegd is de aan hem - eveneens bij wet - toegekende bevoegdheden uit te oefenen. Deze bevoegdheden vallen buiten het bestek van de voor betrekkingen tussen particulieren geldende civielrechtelijke regels. De ondernemingsraad is daarom bij de uitoefening van zijn bevoegdheid krachtens artikel 25 WOR niet gelijk te stellen met een privaatrechtelijke partij. ${ }^{20}$ Een parallel valt te maken met een overheidsorgaan. Indien de overheidsinstantie handelt krachtens de haar bij wet toegekende overheidsbevoegdheid, mist de EEX-Vo. toepassing. Dat is vaste rechtspraak van het Hof van Justitie. ${ }^{21}$ Dat in de rechtspraak voor medezeggenschap geen uitzondering is gemaakt, zoals Zaal stelt, acht ik weinig steekhoudend. Het Hof van Justitie is immers nog nooit in de gelegenheid geweest zich over deze vraag te buigen.

Zou de EEX-Vo. in VLM II in materieel opzicht wel van toepassing zijn geweest - quod non -, dan had de Ondernemingskamer zich in het beroep jegens CityJet onbevoegd moeten verklaren. Niet op grond van artikel 2 EEX-Vo., zoals CityJet stelt, maar op grond van artikel 22 sub 2 EEX-Vo. Dit artikel bepaalt dat ongeacht de woonplaats van verweerder bij uitsluiting bevoegd zijn 'voor de geldigheid, de nietigheid of de ontbinding van vennootschappen of rechtspersonen met plaats van vestiging in een lidstaat, dan wel van de besluiten van hun organen: de gerechten van die lidstaat'. Volgens Zaal is deze bepaling niet van toepassing op een artikel 25 WOR-zaak, omdat het geschil de onderneming en niet een besluit van een orgaan van de rechtspersoon betreft. ${ }^{22}$ Dat lijkt mij niet juist. Het beroep van de ondernemingsraad richt zich op een besluit van een orgaan van de ondernemer (de rechtspersoon). De voorzieningen die de Ondernemingskamer kan treffen bij kennelijke onredelijkheid van het besluit zien op de intrekking van

18 I.A. Haanappel-van der Burg in haar noot bij de VLM II-beschikking van de OK in JAR 2013/67.

19 I. Zaal, Ondernemingskamer is bevoegd kennis te nemen van een geschil jegens een buitenlandse (mede)ondernemer, TRA 2013/39.

20 De EEX-Vo. is in mijn visie wel van toepassing op een rechtsgeschil inzake een ondernemingsovereenkomst in de zin van artikel 32 WOR. De positie van de ondernemingsraad bij het aangaan van een ondernemingsovereenkomst is te vergelijken met de positie van een particulier die een overeenkomst sluit.

21 HvJ EG 16 december 1980, nr. C-814/79, NJ 1982, 97 m.nt. JCS (Staat der Nederlanden/ Rüffer); HvJ EG 14 november 2002, nr. C-271/00, NJ 2003, 598 m.nt. Vlas (Steenbergen/Baten). 
(een deel van) het besluit, alsmede het ongedaan maken van aan te wijzen gevolgen van het besluit. De kwestie valt daarmee onder de materiële werkingssfeer van artikel 22 sub 2 EEX-Vo., zodat de Ierse rechter exclusief bevoegd zou zijn geweest. ${ }^{23}$

Hoewel ik het eens ben met de conclusie van de Ondernemingskamer dat de EEX-Vo. niet van toepassing is, vind ik de wijze waarop de Ondernemingskamer tot dit oordeel komt weinig overtuigend. De Ondernemingskamer acht zich bevoegd omdat het beroep ex artikel 26 WOR betrekking heeft op een interne aangelegenheid van een in Nederland in stand houden onderneming (zie r.o. 3.1). De Ondernemingskamer doet het voorkomen alsof toepassing van de WOR het geschil tot een puur nationale aangelegenheid maakt. Op deze benadering is vanuit een IPR-perspectief wel iets af te dingen. Het geschil vertoont onmiskenbaar grensoverschrijdende elementen: een buitenlandse vennootschap is verweerder, alsmede voorwerp van het geschil. De voorzieningen die de Ondernemingskamer kan opleggen, kunnen bovendien betrekking hebben op de buitenlandse vennootschap. Onder dergelijke omstandigheden valt niet te verdedigen dat van een interne aangelegenheid sprake is.

De Ondernemingskamer had dus moeten nagaan of haar internationale bevoegdheid toekwam. Artikel 26 WOR is een bepaling van relatieve competentie en creëert voor de Nederlandse rechter geen rechtsmacht. Nu het medezeggenschapsrecht mijns inziens buiten de materiële werkingssfeer van de EEX-Vo. valt, is het commune IPR leidend. Artikel 3 (c) Rv kent in een verzoekschriftprocedure aan de Nederlandse rechter rechtsmacht toe indien de zaak voldoende met de rechtssfeer van Nederland is verbonden. ${ }^{24} \mathrm{Nu}$ het beroep is gericht tegen een besluit dat van invloed is op een in Nederland gelegen onderneming, valt goed te verdedigen dat de zaak voldoende verbondenheid kent met de Nederlandse rechtssfeer. Dit geldt temeer nu de ondernemingsraad zijn bestaansrecht aan de toepassing van de WOR ontleent. Daarnaast bestond in deze casus tussen de verzoeken tegen de dochter- en moedervennootschap een dusdanige samenhang dat de Ondernemingskamer haar internationale bevoegdheid ook op artikel 7 Rv had kunnen baseren.

\subsubsection{De materiële werkingssfeer van de EEX-Vo. en het enquêterecht}

Vervolgens verdient de vraag van de bevoegdheid van de Ondernemingskamer in een internationale enquêtezaak beantwoording. Anders dan in VLM II besteedt de Ondernemingskamer in Chinese Workers niet expliciet aandacht aan de internationale bevoegdheidsvraag. Toch liggen de benaderingen in beide zaken niet

23 Zie ook A.V.M. Struycken, De ondernemingskamer vanuit ipr-gezichtspunt bekeken, in: H.J.M.N. Honée (red.), Van vennootschappelijk belang (Maeijer-bundel), Zwolle: Tjeenk Willink 1988, p. 331. I.A. Haanappel-van der Burg verwijst in haar annotatie bij de VLM II-beschikking in JAR 2013/67 naar de bijdrage van Struycken, maar neemt zelf geen standpunt in over de toepassing van artikel 22 sub b EEX-Vo.

24 Artikel 6 (h) Rv kent een aan artikel 22 sub 2 EEX-Vo. gelijke bepaling. Deze bepaling kent - anders dan artikel 22 sub 2 EEX-Vo. - geen exclusieve werking (ook niet op grond van reflexwerking nu medezeggenschap niet onder de materiële werkingssfeer van de EEX-Vo. valt), zodat de Ondernemingskamer haar internationale bevoegdheid op artikel 3 (c) Rv kan baseren. 
F.G. Laagland

ver uiteen. $\mathrm{Nu}$ het verzoek zich richt op een Nederlandse vennootschap en het enquêterecht op het rechtsgeschil van toepassing is, beschouwt de Ondernemingskamer de kwestie (ook nu) als een interne aangelegenheid. Tegen dit oordeel is in cassatie geen klacht gericht.

Hoe is deze aanname van de Ondernemingskamer vanuit een IPR-perspectief te duiden? De Hoge Raad heeft zich in het verleden eenmaal uitgelaten over de toepassing van de EEX-Vo. in een enquêtezaak. Dat was in de e-Traction-beschikking uit 2010. ${ }^{25}$ Een van de voorzieningen die de Ondernemingskamer jegens de Nederlandse vennootschap had opgelegd, zag op de overdracht ten titel van beheer van de door een in Luxemburg gevestigde aandeelhouder gehouden aandelen. In cassatie werd geklaagd over de rechtsmacht van de Ondernemingskamer ten aanzien van de opgelegde voorziening. De Hoge Raad oordeelde dat niet de EEX-Vo. maar de relatieve competentiebepaling van artikel 2:345 BW van toepassing was, omdat zowel het voorwerp van de enquête als degenen die hadden verzocht om het treffen van de voorzieningen woonplaats hadden in Nederland. De buitenlandse aandeelhouder maakte het geschil vanuit een internationaal-privaatrechtelijk oogpunt niet grensoverschrijdend. Hierdoor kwam men aan de EEX-Vo. niet toe.

In e-Traction trad de buitenlandse aandeelhouder op als belanghebbende en was verzoeker noch verweerder. Op dit punt onderscheidt de Chinese Workers-zaak zich van de e-Traction-zaak. In Chinese Workers wordt de enquête verzocht door de aandeelhouder van een buitenlandse vennootschap. Het perspectief is dus een andere. Hoewel de aandeelhouder Yeh-Chiu woonplaats heeft in Nederland (Haarlem), doet Yeh-Chiu het enquêteverzoek vanuit haar hoedanigheid als aandeelhouder van een vennootschap opgericht naar vreemd recht. Dat maakt de kwestie in mijn optiek tot een grensoverschrijdend geschil. De Ondernemingskamer kon haar bevoegdheid in Chinese Workers daarom niet baseren op de relatieve competentiebepaling van artikel 2:345 BW, maar had ambtshalve moeten nagaan of haar internationale bevoegdheid toekwam. ${ }^{26}$ Dat de Ondernemingskamer de buitenlandse vennootschap in haar inhoudelijke oordeel over de toepassing van het enquêterecht 'wegdenkt', doet hier niet aan af. Vanuit een IPR-perspectief wordt de bevoegdheid bepaald voordat de vraag naar het toepasselijke recht aan de orde komt.

Het is interessant na te gaan hoe de beantwoording van de internationale bevoegdheidsvraag vorm en inhoud had moeten krijgen. De considerans van de EEX-Vo. maakt duidelijk dat is bedoeld - met uitzondering van bepaalde duidelijk in de Verordening omschreven onderwerpen - alle burgerlijke en handelszaken onder de materiële werkingssfeer van de EEX-Vo. te brengen. ${ }^{27}$ Het enquêterecht is een burgerlijke of handelszaak: het onderwerp is privaatrechtelijk van aard en het rechtsgeschil speelt zich af tussen twee privaatrechtelijke (rechts)personen.

HR 25 juni 2010, JOR 2010/226 m.nt. Van Solinge (e-Traction).

\footnotetext{
Uit het toelichtende rapport Jennard (PbEU 5 maart 1979, nr. C 59, hoofdstuk III, onder II) volgt dat de verwijzingsregels uit de EEX-Vo. van dwingend recht zijn. Dit houdt in dat de rechter in een geschil dat onder het toepassingsbereik valt ambtshalve zijn bevoegdheid moet nagaan. Zie ook HR 9 februari 2001, NJ 2001, 290 (Premium/Apotheek Schothorst).

Overweging 7 preambule EEX-Vo.
} 
Van Solinge is daarentegen van oordeel dat de EEX-Vo. niet van toepassing is op het Nederlandse enquêterecht. ${ }^{28}$ Van Solinge baseert de internationale bevoegdheid van de Ondernemingskamer in een grensoverschrijdend geschil op regels van intern procesrecht (artikelen $995 \mathrm{Rv}$ en 2:345 BW). Zie ik het goed, dan meent hij dat de internationale bevoegdheid van de Ondernemingskamer voortvloeit uit de toepasselijkheid van het enquêterecht. Deze benadering acht ik niet juist. Uit de regels van intern procesrecht kan niet worden afgeleid dat de Ondernemingskamer internationale bevoegdheid heeft. Zoals gezegd, is de regel dat distributie van rechtsmacht attributie van rechtsmacht schept, sinds 1 januari 2002 verlaten. De interne procesregels treden eerst in werking zodra is vastgesteld dat de Nederlandse rechter rechtsmacht heeft.

In artikel 2 EEX-Vo. vindt men de hoofdregel: bevoegd zijn de gerechten van de lidstaat waar de verweerder woonplaats heeft. ${ }^{29}$ Op deze hoofdregel bestaan uitzonderingen. Een verzoek tot enquête valt onder de exclusieve bevoegdheidsregel van artikel 22 sub 2 EEX-Vo. ${ }^{30}$ De voorzieningen die de Ondernemingskamer kan treffen bij wanbeleid hebben betrekking op het voortbestaan van de rechtspersoon dan wel de geldigheid van door zijn organen genomen besluiten. Artikel 22 sub 2 EEX-Vo. heeft tot doel het bewerkstelligen van 'Gleichlauf' tussen rechterlijke bevoegdheid en toepasselijk recht. ${ }^{31}$ De bepaling verwijst voor de bevoegde rechter naar de rechter van de lidstaat waar de rechtspersoon is gevestigd. De vestigingsplaats wordt bepaald aan de hand van het IPR van de desbetreffende lidstaat. Het Nederlandse recht zoekt voor de vestigingsplaats aansluiting bij de staat naar welk recht de vennootschap is opgericht (artikel 10:118 BW). De Nederlandse rechter (concreet: de Ondernemingskamer) is op grond van artikel 22 sub 2 EEX-Vo. dus bevoegd indien het enquêteverzoek zich richt op een in Nederland gevestigde rechtspersoon. Dit betekent dat ook de EEX-Vo. de Ondernemingskamer in Chinese Workers als de bevoegde rechter zou hebben aangewezen.

De situatie zou anders zijn als het enquêteverzoek in Chinese Workers (ook) was gericht tegen de buitenlandse moedervennootschap Chinnede. De moedervennootschap is gevestigd in Hongkong. Toepassing van de EEX-Vo. leidt op grond van artikel 22 sub 2 dan tot exclusieve bevoegdheid van de buitenlandse rechter. Deze bepaling mist echter (wat de formele werkingssfeer betreft) toepassing, nu de rechtspersoon niet in een lidstaat van de Europese Unie is gevestigd. Men valt terug op het commune IPR. Ook het commune Nederlandse IPR biedt geen hand-

28 G. van Solinge in zijn noot bij de e-Traction-beschikking van de Hoge Raad in JOR 2010/226.

29 De woonplaats van een rechtspersoon wordt bepaald aan de hand van artikel 60 EEX-Vo. Dit artikel kent een autonome begripsbepaling. De woonplaats van een rechtspersoon wordt bepaald op basis van de statutaire zetel, het hoofdbestuur of de hoofdvestiging. Tussen de drie criteria bestaat geen onderlinge hiërarchie.

30 Zie noot 24 met betrekking tot de toepassing van deze rechtsregel in het medezeggenschapsrecht.

31 Zie het toelichtende rapport Jenard, PbEU 5 maart 1979, nr. C 59, p. 35. 
F.G. Laagland

vatten om de bevoegdheid van de Ondernemingskamer op te baseren. Artikel 6 sub h Rv kent immers een aan artikel 22 sub 2 EEX-Vo. soortgelijke bepaling. ${ }^{32}$

\subsection{Het door de Ondernemingskamer toe te passen recht}

In zowel VLM II als Chinese Workers treden in de procedure één of meer vennootschappen op als verwerende partij(en). Het Unierecht geeft geen antwoord op de vraag welk recht op een vennootschap van toepassing is. Bepalend is het commune materiële IPR van de desbetreffende lidstaat. Het Hof van Justitie heeft overwogen dat lidstaten vrij zijn in hun keuze van de aanknopingsfactor voor het toepasselijke recht. ${ }^{33}$ Dit wordt ook wel de free choice of connecting factors genoemd en ligt besloten in artikel 54 van het Verdrag betreffende de werking van de Europese Unie (VWEU). ${ }^{34}$

Het IPR worstelt reeds van oudsher met een in beginsel ${ }^{35}$ tussen twee zetelleren woedende 'loopgravenoorlog': de leer van de werkelijke zetel en de leer van de statutaire zetel. ${ }^{36}$ In de werkelijke zetelleer wordt het toepasselijke recht op de vennootschap bepaald door het recht van het land van de centrale bestuurszetel, dat wil zeggen het land waar zich het centrum van de bestuursactiviteiten bevindt. De statutaire zetelleer knoopt voor het toepasselijke recht aan bij de plaats waar de vennootschap rechtspersoonlijkheid heeft verworven (wat zich principieel uit in de eerste statutaire zetel) dan wel de plaats van haar statutaire zetel. ${ }^{37}$ Waar de vennootschap haar bedrijfs- en/of bestuursactiviteiten uitvoert, is van geen belang. Deze laatste leer hanteert Nederland (artikel 10:118 BW). Artikel 10:119 BW bepaalt dat het inwendige bestel van de rechtspersoon en alle daarmee verband houdende facetten zijn onderworpen aan het op de corporatie toepasselijke recht. Het Nederlandse vennootschapsrecht is dus slechts van toepassing op naar

32 Weliswaar regelt artikel 6 sub h Rv de bevoegdheid van de Nederlandse rechter niet exclusief, maar aannemelijk is dat aan de ratio van artikel 22 sub 2 EEX-Vo. reflexwerking toekomt nu het onderwerp binnen de materiële werkingssfeer van de EEX-Vo. valt. Dit betekent dat ook in het commune IPR de vestigingsplaats van de rechtspersoon exclusief bepalend is voor de bevoegdheid van de Nederlandse rechter bij besluiten die de rechtspersoon aangaan. Vgl. Struycken 1988, p. 331-332. Ook Vlas 2009, p. 210 is van oordeel dat het Nederlandse commune IPR geen kapstok biedt om de bevoegdheid van de Ondernemingskamer op te baseren. Deze benadering gaat niet op voor het medezeggenschapsrecht, nu medezeggenschap niet onder de materiële werkingssfeer van de EEX-Vo. valt (zie noot 24).

33 HvJ EG 16 december 2008, nr. C-210/06, NJ 2009, 202, JOR 2009/35 m.nt. Vossestein (Cartesio), punt 110 .

34 Vossestein in zijn annotatie in JOR 2006/33.

35 Ik heb het over 'in beginsel', omdat het IPR talloze uitzonderingen kent. Zo volgt voor Nederland een uitzondering op de incorporatieleer uit de Wet op de formeel buitenlandse vennootschappen van 17 december 1997, Stcrt. 697.

36 Zie voor een uitgebreide uiteenzetting van beide leren in de Nederlandse literatuur S.F.G. Rammeloo, Vrije verkeer van rechtspersonen in Europa na HvJ EG Überseering. IPR-zetelleercontroverse beslecht?, NIPR 2003/2, p. 134-144 en Vlas 2009, p. 22-31.

37 Beide varianten vallen onder de noemer statutaire zetelleer. Het verschil is dat vennootschappen in de eerste variant hun statutaire zetel niet naar het buitenland kunnen verplaatsen, terwijl die mogelijkheid in de tweede variant wel bestaat. De tweede variant geldt bijvoorbeeld in Zwitserland. 
Nederlands recht opgerichte rechtspersonen. Buitenlandse rechtspersonen vallen buiten het bereik.

\subsubsection{Het toepassingsbereik van de WOR}

De WOR valt niet onder het bereik van artikel 10:119 BW, maar kent een eigen reikwijdtebepaling. De WOR is van toepassing op een binnen de Nederlandse landsgrenzen gesitueerde onderneming in de zin van artikel 1 lid 1 sub c WOR met meer dan vijftig werknemers. Onder het begrip onderneming verstaat de wet 'elk in de maatschappij als zelfstandige eenheid optredend organisatorisch verband waarin krachtens arbeidsovereenkomst arbeid wordt verricht'.

De rechtsvorm van de ondernemer is irrelevant voor de toepassing van de WOR. Evenmin is van belang of de (rechts)persoon die de ondernemer in stand houdt in Nederland dan wel het buitenland is gevestigd. Deze benadering leest men voor het eerst terug in een beschikking van de minister van Sociale Zaken uit de jaren zeventig van de vorige eeuw. ${ }^{38}$ De beschikking had betrekking op een ontheffingsverzoek. Uit de beschikking vloeit de gedachte voort dat Nederlandse vestigingen van buitenlandse ondernemingen zich aan de hier te lande geldende wetten en gebruiken dienen aan te passen. De redenering keert terug in een beschikking uit 1976 met de toevoeging dat 'daaronder (...) ook de Wet op de ondernemingsraden is begrepen'. ${ }^{39}$ Polak leidde in 1988 uit de twee beschikkingen af dat de WOR van toepassing is op een buitenlandse ondernemer (natuurlijke of rechtspersoon) met een Nederlands filiaal dat voldoet aan het ondernemingsbegrip in de zin van de WOR. ${ }^{40}$ Deze zienswijze geldt tegenwoordig als een vaststaand gegeven. ${ }^{41}$ De lijn is in de VLM I-beschikking doorgetrokken naar een buitenlandse ondernemer die als medeondernemer wordt beschouwd. ${ }^{42}$

De benadering strookt met het materiële IPR. Wat is immers het geval? De WOR heeft door de oriëntatie op het algemene belang mede een publiekrechtelijke inslag. Het gaat om een regeling van sociaaleconomisch ondernemingsrecht. ${ }^{43} \mathrm{De}$ voorschriften in de WOR zijn daarom te kwalificeren als voorrangsregels. Dit geldt voor zowel de voorschriften die invloed hebben op de verhouding tussen de ondernemer en een individueel ondernemingsraadslid (ontslagbescherming en doorbetaling van loon tijdens OR-werkzaamheden) als de voorschriften die aan de ondernemingsraad als collectief toekomen (informatie, raadplegings-, advies- en instemmingsrechten). Hoewel de collectieve voorschriften niet van directe

38 Minister van Sociale Zaken 9 april 1974, Rechtspraak medezeggenschapsrecht 1971-1981, nr. 12 m.nt. Geersing.

39 Minister van Sociale Zaken 3 februari 1977, AB 1977, nr. 263 m.nt. Van der Ven. Het tegen deze beschikking ingestelde beroep is verworpen door de Afdeling rechtspraak van de Raad van State, 26 mei 1987, Rechtspraak medezeggenschapsrecht 1971-1981, nr. 6 m.nt. Geersing.

40 M.V. Polak, Arbeidsverhoudingen in het Nederlandse internationaal privaatrecht, Deventer: Kluwer 1988, p. 142.

41 Zie onder meer Rood/Verburg, Wet op de ondernemingsraden, Deventer: Kluwer 2013, p. 39; Bartman \& Dorresteijn, Van het Concern, Deventer: Kluwer 2009, p. 195.

42 HR 3 februari 2012, JAR 2012/71 (VLM I) m.nt. Van het Kaar in TRA 2012/39.

43 Zie over voorrangsregels in het algemeen A.P.M.J. Vonken, Mr. C. Assers Handleiding tot de beoefening van het Nederlands Burgerlijk Recht. Deel 10-1 IPR Algemeen deel, Deventer: Kluwer 2013, nr. 480. 
F.G. Laagland

invloed zijn op een privaatrechtelijke rechtsverhouding tussen werkgever en werknemer, kunnen zij civielrechtelijke gevolgen hebben voor de besluitvorming van de ondernemer.

De vraag of een voorrangsregel in een internationale kwestie gelding heeft, wordt bepaald aan de hand van de 'scope rule' van de betreffende regel. De 'scope rule' is een eenzijdige verwijzingsregel die het territoriale toepassingsbereik van de voorrangsregel afbakent en is in de WOR te vinden in artikel 1 lid 1 sub c. Voor de toepassing van de WOR is dus bepalend dat de onderneming in de zin van de WOR in Nederland is gelegen. Dit verklaart waarom in VLM II de vraag naar de toepassing van de WOR niet ter discussie stond. Indien CityJet en VLM Airlines als medeondernemers zouden zijn aangemerkt (een vraag waarover de Ondernemingskamer zich niet hoefde uit te laten), zouden zij beide zijn gevallen onder het regime van de WOR. De Ondernemingskamer had bij de vaststelling dat het besluit kennelijk onredelijk was de voorzieningen uit artikel 26 lid 5 WOR ook jegens de buitenlandse vennootschappen kunnen opleggen.

\subsubsection{Het toepassingsbereik van het enquêterecht}

De incorporatieleer is relevant voor de toepassing van het enquêterecht. Hoewel de niet-limitatieve opsomming van artikel 10:119 BW de regeling van het enquêterecht niet expliciet noemt, is algemeen aangenomen dat het enquêterecht valt onder de onderwerpen die worden beheerst door het recht van de statutaire zetel. ${ }^{44}$ Deze benadering is in lijn met artikel 2:344 BW, dat de toepassing van het enquêterecht beperkt tot de aldaar genoemde, naar Nederlands recht opgerichte rechtspersonen. Een buitenlandse vennootschap kan geen voorwerp zijn van een enquêteprocedure. ${ }^{45}$ Dit is niet anders indien de buitenlandse vennootschap in Nederland haar voornaamste ondernemingsactiviteiten houdt. De Wet op de formeel buitenlandse vennootschap (Wfbv) schaart het enquêterecht niet onder haar toepassingsbereik, en het enquêterecht kan ook niet via die band op een formeel buitenlandse vennootschap van toepassing worden verklaard. ${ }^{46}$ Ook speelt geen rol of de aandelen van de buitenlandse vennootschap volledig in handen zijn van een Nederlandse vennootschap. ${ }^{47}$

Hoe is in dit licht het oordeel in Chinese Workers te duiden? Ik stel allereerst vast dat de aandeelhouder van de buitenlandse moedervennootschap geen beroep deed op een zogenoemde concernenquête. Als sprake is van een economische en organisatorische eenheid onder een centrale leiding, kunnen aandeelhouders of

44 Van Solinge 2012, p. 205; Asser/Maeijer/Van Solinge \& Nieuwe Weme 2009(2-II*), nr. 735.

45 HR 13 mei 2005, JOR 2005/147 m.nt. Josephus Jitta (Zeelandia/Curaçao). De Hoge Raad oordeelde dat de beperking tot Nederlandse vennootschappen niet meebrengt dat de onderzoeker geen gegevens mag verzamelen over het beleid van in het buitenland gevestigde rechtspersonen die betrekkingen onderhouden met de rechtspersoon die het voorwerp van de enquête is. In zoverre geldt het territorialiteitsbeginsel niet in zeer strikte zin. Dit neemt niet weg dat de voorzieningen slechts kunnen worden getroffen indien van wanbeleid bij de Nederlandse vennootschap is gebleken. De voorzieningen kunnen ook louter de Nederlandse vennootschap betreffen. Zie ook HR 18 augustus 2005, JOR 2005/271 (Dubbelhuis en De Olde Molen).

46 Hof Amsterdam (OK) 16 juli 2004, JOR 2004/230 (Citadel Beheer).

47 HR 18 augustus 2005, JOR 2005/271 (Dubbelhuis en De Olde Molen). 
certificaathouders van de moedervennootschap ook bij haar dochtervennootschap(pen) een enquête verzoeken. De Hoge Raad heeft deze bevoegdheidsdoorbraak binnen concernverband voor het eerst aanvaard in de Landis-beschikking uit 2005. ${ }^{48}$ Een concernenquête vereist evenwel dat een enquête bij de moedervennootschap wordt verzocht en toegewezen alvorens een onderzoek bij de dochtervennootschap kan worden gelast. Deze benadering - die in de literatuur bekendstaat als de 'afgeleide leer' 49 - verklaart waarom de aandeelhouder van de buitenlandse vennootschap in Chinese Workers niet zijn heil zocht in de techniek van een concernenquête. $\mathrm{Nu}$ de aandeelhouder geen enquête jegens de buitenlandse moeder kon verzoeken - dat was immers een vennootschap naar het recht van Hongkong - was het evenmin mogelijk via een bevoegdheidsdoorbraak een enquêteverzoek naar het beleid van de dochter te gelasten. ${ }^{50}$

De tactiek die werd beproefd in Chinese Workers onderscheidt zich in die zin van de concernenquête dat de aandeelhouder van de buitenlandse moeder het enquêteverzoek rechtstreeks tot de Nederlandse dochter richt. Deze tactiek werpt, naar blijkt, haar vruchten af. Zowel de Ondernemingskamer als de Hoge Raad beschouwt de aandeelhouder van de buitenlandse vennootschap als een economisch gerechtigde ten aanzien van de aandelen in de dochter. ${ }^{51}$ Het lijkt alsof de Hoge Raad het feit dat de weinig betekenisvolle moedervennootschap 'toevalligerwijs' buitenlands is door de gehanteerde constructie probeert te omzeilen. Puur gelet op de - overigens zeer summiere - motivering spreekt de Hoge Raad over een uitbreiding van degenen aan wie de bevoegdheid tot het indienen van een enquêteverzoek toekomt. De Hoge Raad laat de overweging van de Ondernemingskamer in stand dat de buitenlandse moeder kan worden 'weggedacht', omdat (1) de moeder uitsluitend de aandelen van de dochter beheerde, (2) er geen reden was voor het beheer vanuit Hongkong, (3) alle ondernemingsactiviteiten door of in opdracht van de dochter werden verricht, en (4) de door de uitzendbureaus verschuldigde commissie door de aandeelhouders van de moeder werd gefactureerd en door de uitzendbureaus rechtstreeks aan de aandeelhouders van de moeder werd betaald.

48 HR 4 februari 2005, NJ 2005, 127, JOR 2005/58 (Landis). Het ging in Landis om een drie $100 \%$-dochtervennootschappen. In de besturen van de moeder en haar drie dochters zaten grotendeels dezelfde personen. De Hoge Raad overwoog dat in de dochtervennootschappen geen sprake was van enig ten opzichte van de moedervennootschap zelfstandig bepaald en gevoerd bestuursbeleid. Om die reden raakten het beleid en de gang van zaken van de dochtervennootschappen de belangen van de aandeelhouders in de moedervennootschap evenzeer en op gelijke wijze als het beleid en de gang van zaken van de moedervennootschap zelf, en was een doorbraak van de enquêtebevoegdheid toegestaan. Een concernenquête is na Landis door de Ondernemingskamer ook toegestaan bij minder dan 100\% aandeelhouderschap. Zie: Hof Amsterdam (OK) 25 maart 2005, JOR 2005/177 (Euroyal), Hof Amsterdam (OK) 20 juli 2005, ARO 2005/119 (BKV), Hof Amsterdam (OK) 22 maart 2006, JOR 2006/180 (Van Doorn) en Hof Amsterdam (OK) 27 december 2006, ARO 2007/4 (Woudwood).

49 S.M. Bartman, Grenzeloos enquêterecht, AA 2012 mei, p. 383.

50 Vgl. HR 8 april 2011, JOR 2011/178 (TESN).

51 De Hoge Raad gaat met zijn oordeel lijnrecht in tegen advocaat-generaal Vlas en de opvattingen in de literatuur. Voor een analyse van de verschillende visies verwijs ik naar het artikel 'Nederlands enquêterecht in internationale concernverhoudingen' dat ik samen met C.M. van Boekel schreef in TAO 2013/3. 
F.G. Laagland

Voor de benadering van de Hoge Raad pleit dat de buitenlandse vennootschap niet fungeert als het onderwerp van het enquêteverzoek. In dat licht kan men stellen dat het slechts ging om de rechtsvraag wie enquêtegerechtigd was. Dat kan - naar nu blijkt - een aandeelhouder van een buitenlandse vennootschap zijn, voor zover de buitenlandse vennootschap op grond van de economische werkelijkheid kan worden 'weggedacht'. Nu het gaat om de toepassing van het enquêterecht en de vraag wie enquêtegerechtigd is, is de aanknoping bij de economische werkelijkheid niet vreemd. De economische werkelijkheid ligt ten grondslag aan de in de rechtspraak geaccepteerde uitbreiding van de kring van enquêtegerechtigden tot de economische gerechtigde, dat wil zeggen de verschaffer van risicodragend kapitaal met een eigen economisch belang in de vennootschap waarop het verzoek zich richt. De gedachte is dat degene die uiteindelijk het kapitaal aan de vennootschap verschaft en daarmee dus het economische risico loopt, de mogelijkheid moet hebben zijn belangen via de enquêteprocedure in rechte te behartigen. ${ }^{52}$

Vanuit een IPR-perspectief is de aanknoping bij de economische werkelijkheid minder goed te plaatsen. Kijken we naar de criteria die tot het 'wegdenken' in Chinese Workers aanleiding geven, dan valt op dat belangrijke betekenis toekomt aan de plaats van de ondernemingsactiviteiten. In navolging van de Ondernemingskamer motiveerde de Hoge Raad zijn oordeel dat aan de buitenlandse moeder geen betekenis toekomt met verwijzing naar het feit dat 'alle ondernemingsactiviteiten plaatsvinden in de Nederlandse vennootschap en de moeder in feite niet meer is dan een administratiekantoor' (r.o. 3.6). Het aspect 'de plaats van de ondernemingsactiviteiten' onderscheidt de Chinese Workers-beschikking van de TESN-beschikking uit 2011. Ook in de TESN-beschikking was de buitenlandse moedervennootschap louter opgericht om fiscale motieven en voerde de moeder geen zelfstandig beleid. Toch werd de buitenlandse moedervennootschap in TESN niet weggedacht, omdat - zoals de Ondernemingskamer het overwoog - de ondernemingsactiviteiten buiten Nederland plaatsvonden (r.o. 3.8). Het onderscheidende criterium 'de plaats van de ondernemingsactiviteiten' doet denken aan de systematiek uit de WOR die voor de toepassing aansluit bij een in Nederland gelegen onderneming in de zin van de WOR. Het criterium past evenwel niet goed binnen het juridische bestel van het enquêterecht dat de vennootschap als object kent en via het incorporatiestelsel buitenlandse vennootschappen van het toepassingsbereik uitsluit.

De benadering van de Hoge Raad is vanuit een IPR-perspectief dogmatisch dus niet juist. De Hoge Raad kon het feit dat de verzoeker aandelen hield in een buitenlandse moeder op grond van de economische werkgelijkheid niet onbesproken laten. Deze conclusie neemt niet weg dat ook ik mij kan vinden in de gedachte dat geen doorslaggevende betekenis dient toe te komen aan het feit dat de moedervennootschap buitenlands is indien zij geen zelfstandig beleid voert en alle ondernemingsactiviteiten in Nederland plaatsvinden. Die gedachte moet alleen wel verenigbaar zijn met het IPR. Ik zie twee mogelijke oplossingen. 
Verbrugh en Timmerman deden in 2009 de suggestie de Wfbv uit te breiden tot het enquêterecht in verlichte vorm (zonder het treffen van definitieve voorzieningen). ${ }^{53}$ Deze oplossing heeft een breder bereik dan de casus uit Chinese Workers en omvat ook de buitenlandse vennootschap die zonder tussenkomst van een Nederlandse dochter al haar ondernemingsactiviteiten in Nederland ontplooit. De wetgever heeft aan hun oproep tot dusver geen navolging gegeven. Een oplossing die reeds nu uitsluitsel kan bieden, is de IPR-techniek van assimilatie. Bij assimilatie wordt een rechtsverhouding die juridisch is vormgegeven door het buitenlandse recht in Nederland erkend, in die zin dat zij wordt geassimileerd (geïntegreerd) met een rechtsfiguur uit het Nederlandse recht. ${ }^{54}$ Meer concreet: de rechtsregels die zijn toegesneden op een interne rechtsverhouding worden verruimd voor toepassing op een internationale rechtsverhouding die wat aard en functie betreft gelijk is aan de interne rechtsverhouding. In een situatie waarin de buitenlandse vennootschap niet meer is dan een administratiekantoor en alle ondernemingsactiviteiten in Nederland plaatsvinden, acht ik verdedigbaar dat de buitenlandse vennootschap niet van een Nederlandse vennootschap is te onderscheiden. In een dergelijke situatie kan de buitenlandse vennootschap - via de interpretatietechniek van assimilatie - onder het toepassingsbereik van het enquêterecht worden gebracht, zodat de aandeelhouder van de buitenlandse vennootschap met een beroep op de concernenquête een verzoek naar het beleid in de dochter kan doen.

\section{Slotbeschouwing}

De deskundigheid van de Ondernemingskamer is een sterk element in de toepassing van de WOR en het enquêterecht. Deze combinatie moet worden gekoesterd. Dit uitgangspunt stelt het IPR echter niet ter zijde. Bij internationale geschillen moet de vraag naar de bevoegde rechter los van de vraag naar het toepasselijke recht worden beoordeeld. De Ondernemingskamer heeft het onderscheid tussen beide IPR-aspecten niet duidelijk voor ogen. In zowel de VLM II-beschikking als de Chinese Workers-beschikking gaat de Ondernemingskamer ervan uit dat de toepassing van de WOR dan wel het enquêterecht leidt tot haar bevoegdheid over het internationale geschil te kunnen oordelen. Nu kan men mij tegenwerpen dat mijn bezwaren vooral rechtstheoretisch van aard zijn. Mijn bevindingen tonen immers aan dat de uitkomst van beide beschikkingen niet anders had hoeven zijn indien de juridisch juiste weg van het IPR zou zijn bewandeld. Dat moge waar zijn. Het neemt niet weg dat van de Ondernemingskamer mag worden verwacht dat zij ook het IPR correct toepast.

53 M.A. Verbrugh \& L. Timmerman, Het Nederlandse enquêterecht in een internationaliserend vennootschapsrecht, Ondernemingsrecht 2009, p. 35. 